\title{
ÇAĞDAŞ TÜRK ROMANININ SORUNLARI VE ROMANDA YENİ AÇILIMLAR*
}

\section{Osman GÜNDÜZ**}

Geliş Tarihi: Nisan, 2016

Kabul Tarihi: Haziran, 2016

$\ddot{O} z$

Tanpınar 1930'lu yıllarda yazmış olduğu Bizde Roman başlıklı yazısında roman yazarlarının, Türk toplumuna Batılı romancıların penceresinden baktıkları için, "samimi” olamadıklarından ve bununla bağlantılı olarak Türk romanının henüz "intikal" dönemini tamamlamamış olduğundan yakınır. Tanpınar'dan yaklaşık otuz yıl sonra ünlü romancı Kemal Tahir ise 1945'lere kadar Türk romancılarının kendi toplumlarını derinliğine tanımadıklarından dolayı "Batı romanının kopyacısı" hâline geldiklerini söylemektedir.

Ne ki tek bir eserle roman dünyasına adım attığımız 1872 yılından bugüne gelinceye kadar 140 yıla yakın bir zaman geçti. Özellikle son yıllarda yayımlanan romanlar Cumhuriyet tarihimizde eşi görülmemiş bir hacme ulaştı ve o ölçüde ilgi gördü. Öyle ki kimi romanların baskısı yüzbinleri bulurken kimileri 500, 600 baskı sayısıyla milyonlarla buluştu. Kuşkusuz bu tablo okuma sorunu olan bir toplum için pek çoğumuzca belki iyimserlikle karşılanabilir, ama nitelik bakımından aynı düşünceleri paylaşmak zor. Öte yandan eserlerin önemli bir bölümü, ciddi bir eleştiri yerine 1smarlamacı anlayışa göre yorumlandıkları için, nitelikleriyle değil, niceliksel yanlarıyla dikkati çektiler. Öyle ki iyi eser okuyucusunu bulur genel ve yerleşik yargısı, yerini, iyi reklam daha çok okur ve doğal olarak çok gelir getirir yargısına bıraktı. $\mathrm{Bu}$ yazıda söz konusu sorunlar dikkate alınarak Türk romanının bugünkü durumu incelenmektedir.

Anahtar Sözcükler: Çağdaş Türk romanı, postmodern roman, polisiye roman, bilimkurgu roman, fantastik roman.

\section{THE PROBLEMS OF MODERN TURKISH NOVEL AND NEW DEVELOPMENTS IN THE NOVEL}

\begin{abstract}
In the writing that Tanpınar wrote in 1930s with the heading Bizde Roman, he complains that the novelists, as they see the Turkish society from the view of Western works, cannot be "intimate" and in accordance with this, Turkish novel has not completed its "transition" period. 30 years after Tanpınar, famous novelist Kemal Tahir said that Turkish novelists had become the imitators of Western novel as they did not know their own society very well. However, 140 years have passed since 1872 when we stepped into the novel world with a work. The novels published especially in recent years have caught a great attention that has never been seen in our Republic history. In fact, while the publications of some novels have reached hundred thousands, some have reached to millions with 500, 600 publications. Undoubtedly, this table may be considered in an optimistic way
\end{abstract}

\footnotetext{
${ }^{*}$ Bu yazı, V. European Conference on Social and Behaviorial Sciences St. Petersburg-Russia Septamber 11-14 2014 tarihleri arasında yapılan programın 13.09.2014 tarihli 7. oturumunda bildiri olarak sunulmuş; düzeltme, ekleme ve güncellemeler yapılarak makaleye dönüştürülmüştür.

** Prof. Dr.; Atatürk Üniversitesi, KKEF. Türkçe Eğitimi Bölümü, ogunduz25@gmail.com.
} 
by many of us for society that has reading problem, but it is difficult to share the same ideas in terms of quality. In addition, a significant part of the works has caught the attention thanks to their quantitative sides not the qualitative ones as they are interpreted with an ordered understanding instead of a serious criticism. Therefore, the judgement that a good advertisement gets more readers and more money has replaced the general and settled judgement that a good work finds its reader. In this declaration, the current situation of Turkish novel will be studied by taking the problems into consideration.

Keywords: Modern Turkish novel, postmodern novel, crime novel, science fiction novel, fantastic novel.

\section{Çağdaş Türk Romanının Sorunları ve Romanda Yeni Açııımlar}

Günümüzde roman, altın çağını yaşadığı 19. yüzyıl kadar olmasa bile yine de edebiyatın gündemini belirleyen ve kamuoyunun beklentilerini karşılayan bir tür olarak kabul görmektedir. Bunun gereği olarak özellikle son yıllarda yayımlanan romanlar Cumhuriyet tarihimizde eşi görülmemiş bir hacme ulaştı ve o ölçüde ilgi gördü. Öyle ki kimi romanların baskısı onbinleri bulurken kimileri 500, 600 baskı sayısıyla milyonlarla buluştu. Söz gelişi 2004 yılında 260, 2005 yılında 364, 2013 yılında ise 428 kimilerine göre 500'e yakın roman yayımlanmış olması aynı zamanda türün niceliksel boyutu hakkında da bilgi vermektedir.

$\mathrm{Bu}$ sonuç elbette ki toplumun kitaba ve okumaya ilgisizliği dikkate alınırsa Türk romanı için başarı olarak kabul edilmelidir. Ne var ki reklam ve algı oluşturma yoluyla kendilerine okur bulan pek çok roman yazarı, birbirine benzer ürünleriyle güncelin sınırlarını aşamadı. Sonuçta yazılanların önemli bir bölümü, ciddi bir eleştiri yerine 1smarlamacı ya da Cenab Şahabettin'in özlü sözüyle söyleyeyim: "ver takdirini al takdirimi” anlayışına göre yorumlandıkları için, nitelikleriyle değil, niceliksel yanlarıyla dikkati çektiler. Öyle ki iyi eser okuyucusunu bulur genel ve yerleşik yargısı yerini, iyi reklam eseri daha çok okuyucuya ulaştırır ve doğal olarak çok gelir getirir yargisina biraktı.

Romanımızın içinde bulunduğu bu durumu daha iyi anlayabilmek için yalnız eserleriyle değil kuramsal yazılarıyla da tanınan iki romancımızın kaygılarına dikkat çekmek istiyorum: Bunlardan ilki Türk romanı için yaptıklarının anlaşıldığını göremeden aramızdan göçen Tanpınar'a ait. Tanpınar, yaklaşık seksen yıl önce yayımladığı Bizde Roman başlıklı yazısında okuyucuların, özellikle ünlü romanları kendi dillerinden okuyanların bir süre sonra "münferit eserler" dışında, Türk romanlarından zevk alamayacaklarını söylemektedir. Tanpınar, aynı yazıda, bu "yok"luğun sebeplerine de iner ve yokluğu iki sebebe bağlar: Birincisi roman yazarlarının, Türk toplumuna batılı romancıların penceresinden baktıkları için, "samimi" olamadıkları; buna bağlı olarak ikincisi de, Türk romanının henüz "intikal” dönemini tamamladığı düşüncesidir. Zira, roman kişilerinin ve romanlarda ele alınan sorunların, hatta işlenen temel izleklerin yerli olmasına karşılık; romancılar, yeteri kadar okumadıklarından, 
hayatın gerçekleri ile aralarında sağlam bir ilişki kuramamışlardır. Bu yüzden Türk romanı, “cansız"dır ve yine bu yüzden "sun' 'i” olmaktan kurtulamamaktadır (Tanpınar, 1977: 45-48).

Tanpınar, aynı adı taşıyan ikinci yazısında (1930'lu yıllara göre) ilkinde belirlediği sorunların ayrıntısına iner. Önemli bulduğum görüşlerini özetleyerek aktarayım: Türkiyede yerleşmiş bir roman geleneği yoktur. Mevcut romanlar ise Avrupaî bir gözle eleştirecek/inceleyecek eleştirmenlerden yoksun olarak gazete köşelerinde yitip gitmektedir. Öte yandan roman yazarlarımız da kendi eserleri dışında kalan romanlar üzerine yazı yazmaktan çekinmektedirler. $\mathrm{Bu}$ yüzden bizde eleştiri, "mersiye ile beraber" yürümektedir. Yani bir yazardan şöyle genişçe söz edebilmek için onun ölümünü beklemek gerekmektedir. Tanpınar, bu eksikliği ülkede "elektrikli edebiyat", ya da geniş anlamıyla sanat havasının oluşmadığına bağlamaktadır. Ülkenin roman yazmak için uygun olmasına karşılık, henüz "yaratılış" için oluşum sürecini tamamlamamıştır. Ayrıca bizde aydınlar dışında toplumsal sınıflar oluşmamış; alınan yanlış eğitimin de tesiriyle, romancılarımız, Meşrutiyetten bu yana bireyi anlatmak yerine "umumi hayat"1 anlatmayı benimsemişlerdir. Bireyi anlatmanın yolu ise kendi iç dünyasına eğilmekten geçmektedir. Zira roman yazarı, kendini tanımakla ve kendini anlatmakla başka insanları da anlatmış olacaktır. (Tanpınar, 1977: 49-51).

Benzer kaygıları bu alanda birikimi olan ve Türk romanına yoğun emek harcayan romancılar da taşımaktadır. Söz gelişi Tanpınar'dan yaklaşık otuz yıl sonra Kemal Tahir 1945'lere kadar Türk romancılarının kendi toplumlarını derinliğine tanımadıklarından dolayı "Batı romanı(nın) kopyacı(s1) hâline" geldiklerini söylerken (Solok, 2004: 185; Ulus 11.8.1967'den nakil), günümüz yazarlarından Hilmi Yavuz, Türk romanını “Batı romanının art zamanl bir varyantı" (Torun, Kitap/Haber 14: 27) olarak nitelemektedir.

Tanpınar'ın yukarıdaki tespitlerinden yaklaşık altmış yıl sonra, Türk Edebiyatı dergisinin açmış olduğu soruşturmada yargılar yine aynı. Söz gelişi Sevinç Çokum bizde romanların Avrupa ölçüsünde olmasa da sadece aydınlar arasında ilgi gördüğünü, romanın halk denilen geniş kitlelere yayılamadığını söylerken; Alev Alatlı, romancıların uzun sayılabilecek bir süre ideolojik söylemlere takılıp kaldıkları için Türk romanının bir fetret devri yaşadığını, bu yüzden okurla bire bir ilişski kuramadıklarını ve içinde yaşadıkları toplumla yabancılaştıklarını söyler. Yeni romancılardan Ayla Kutlu da aradan bu kadar yıl geçmesine rağmen Türk romanında değişen fazla bir şey olmadığını düşünüyor: "Kanımca Türk edebiyatının sorunu ne yapısalcılıktır, ne postmodernizmdir, ne anlaşılmaz, karışık aktarımlarla büsbütün kafa karıştıran letterizmdir... vesaire. Türk sanatçısının sorunu, kendi toplumunu tanıyamamasıdır. Yani hâlâ, yabanlar olarak yaşamamızdır." (Kutlu, 1998: 317).

Oysa son yarım yüzyılda Türk toplumu önemli sosyal olaylar yaşadı, 27 Mayıs, 12 
Mart, 12 Eylül askeri darbeleri gibi büyük yıkımlara ve travmalara yol açan değişimler geçirdi. Toplumun her kesimini derinden sarsan/etkileyen Güneydoğu olayları, büyük yıkımlara ve can kayıplarına yol açan depremler, siyasal istikrarsızlıklar ve buna bağlı olarak ekonomik krizler, derin devlet kavramı içinde yer alan Ergenekon, Balyoz tutuklamaları, Gezi olayları, 17, 25 Aralık soruşturmaları, paralel yapılanma gibi daha saymadığım pek çok şey yaşandı. Bütün bu değişimler/olaylar yeteri kadar romana yansıdı mı? Buna da evet demek zor. Ama bu konuda yeni romancılardan Orhan Pamuk daha iyimser düşüncelere sahip. Görüşleri yer yer Tanpınar'la örtüşen Pamuk'a göre "bizim yavaş yavaş dinlerin, büyük ideolojilerin, büyük kuramların baskısından kurtulup kendi hayatımızın anlamını, kendi gündelik hayatımızda ara(dığımız)" gün sorun kendiliğinden çözülecektir (Pamuk, 1994: 244).

$\mathrm{Bu}$ romancılarımızın kaygılarını ve bu kaygıların nedenlerini anlayabilmek için romanımızın son 50 yılda geçirmiş olduğu değişimi ve açılımları ana hatlarıyla vermek istiyorum:

Cumhuriyetle birlikte Cumhuriyet idaresinin okullarında yetişen gençler, çok partili düzene geçmenin hazırlıkları içinde bulunan ülkede gittikçe artan ülke sorunlarını irdeleyen, ortaya koyan, çözüm arayan bir yol tutarlar. Kimileri doktriner reçetelerle benzer konuları tekrarlamanın kolaylığında romancılıklarını sürdürürken, kimileri konularını daha çok batılılaşma çerçevesi içinde Doğu-Batı çatışması ile sınırlı tutarlar. Ne ki hayatın gerçeklerinden ve toplumdan uzakta, yaşananı değil düşsel olanı anlatan ya da tek sorunları aşk, sevda ve bu yolda entrika kurmaktan ibaret olan kişilerin hayatlarını ele alan popülist romancılar, eserlerinin sayısı azalmakla birlikte yine benzer konuları işlemekte, yine entrikaya dayalı romantik aşklardan söz eden romancılıklarını sürdürürler. Ne var ki bu eserlerin bir sanat eseri kimliğini taşıması için pek çok çabaya, emeğe ama bunlardan daha fazla sanatçı sorumluluğuna gereksinim duyduğu kesindir.

1950’li yılların romanında "aydın bakışının egemen" olduğu "aydınlanma" ve “aydinlatma" ön plandayken, (Andaç, 1998: 180) 60’l1 y1llardan sonraki romanlarda aydınlatmanın yanında insanı tanıma ve iç dünyasına nüfuz etme ön plana geçer. Romancı; artık topluma tepeden bakan ve onu yönlendiren, kendisini ilahi güçlerle donanmış doğaüstü bir varlık görmez; insanlara yaklaşır, onu tanımaya, onun güvenini kazanmaya ve onunla arkadaş, dost olmaya çalışır. Konu bulmakta güçlük çeken Türk romancısı, köy konulu romanlarla kendine bir çıkış yolu bulur. Artık Anadolu/taşra/kasaba/köy, tüm sorunlarıyla, sosyoekonomik ve sosyokültürel hayat tarzıyla, feodal düzeniyle, ağa-1rgat, yönetici-köylü, mütegallibe-köylü, ezen-ezilen, varsıllık-yoksulluk kutupluluğuna dayalı bir çizgide yoğun olarak romana girer ve 70’li yıllara kadar romanların birincil kaynağı olur. 
Anadolu köy ve kasabalarını konu alan romanc1lardan kimileri, ideolojik bir tek yanlılıkla, benzer konuları tekrarlamanın kolaylığında, köy/kasaba sorunlarını işlemeyi ısrarla sürdürürken; kimileri bir süre sonra kent insanının ve büyük kentin sorunlarını ele alan konulara yönelir; kimileri Anadolu kent ve kasabalarındaki insanların bireysel sorunlarını ele alır; kimileri de roman kişilerinin sorunlarına toplumcu-gerçekçi bir dikkatle yaklaşırlar. Farklı bir bakışla köy konulu romanların genel şablonu üç ayak üzerine oturtulur. Birinci grubu yoksul ve cahil köylüler yani sömürülenler; ikinci grubu, ağa, onun işbirlikçileri imam, muhtar, parti temsilcileri; üçüncü grubu ise bunlarla mücadele eden ya da bu kişilerin yanında yer alan ülkücü öğretmen, çağdaş değerlere inanmış kaymakam / kasaba doktoru ve bazı bilge köylüler oluşturur.

1960 sonrası romancıları arasında farklı sanat şubelerine mensup, arayış içinde olanlar da var. Bunlardan kimileri romanlarını bir felsefî̀ sisteme dayandırmanın endişelerini taşırken, kimileri de belki tam özümseyemedikleri, dolayısıyla tekyanlılıktan kurtulamadıkları sanat anlayışlarıyla kendilerine bir yer edinmeye çalıştılar. 1960 anayasasının sağladığı özgürlük ortamı ve çok partili hayat beraberinde yol ayırımlarını ve kutuplaşmaları getirdi. Köyden kente yapılan yoğun göç dalgaları, çalışan sınıfların, haklarını korumak ve kendilerini güvence altına almak için örgütlenmeleri, çarpık bir şekilde büyüyen kentin bunaltıcı sorunları, beraberinde aynı amaç için aynı düşünceyi paylaşanların dayanışmasını zorunlu kıldı. Farklı düşüncelere, dünya görüşlerine sahip bu gruplaşmaların düşünsel cephesi ister istemez sanat alanının her şubesinde yankısını bulacaktı. Nitekim 1960’lı yıllardan itibaren Türk romanında ideolojik bir yaklaşımla romanlarını sınıf çatışmasına dayandıran romancılar çoğunluktadır. Ancak bu romancılar, bir yanlarıyla ideolojik ve sınıfsal bir çatışmayı işlerken, bir yanlarıyla hümanist bir tavır sergilediler. Bu tavrın arka planında ezileni, aşağılananı koruma içgüdüsünü de bünyesinde barındırdığı düşünülebilir. Romanlara bu açıdan bakıldığında ele alınan sorunların yöresel, etnik, dinsel ayrılıkların ötesinde uluslarüstü bir nitelik kazandığı görülecektir. Amaç, insanların ortak yanlarını ortaya çıkarmaya çalışmaktır. Bu tür romanlarda din ya da kültürel kimlik ikinci plandadır. Aslolan kişilerin hangi sınıfa ait olduklarıdır. Bu sınıfsal ayırımlar ise varsıllık-yoksulluk, ezen-ezilen, işveren-işçi, ağaırgat kutupluluğunda düğümlenmektedir. Ortak tavır, yoksulun, ezilenin yanında, varlıklının, güçlünün karşısında olmaktır. Ancak, farklı ideolojik ve sınıfsal yaklaşımların kesin çizgileriyle birbirinden ayrıldıklarını da rahatlıkla söyleyemeyiz. Bunlar, yeri geldikçe, ulusal söylemleriyle ve ülkenin bağımsızlığını savunan görüşleriyle öne çıtılar. Romanlarda dış düşmanlara da çoğu kez ulusalcı bir dikkatle bakıldı. Bunların ortak özelliklerinden biri de romanlarda devlete ait değerlerin ve 'devlet' uygulamalarının eleştirilmesidir. Ortak bakış açılarına göre devlet sosyal bir kurum olmaktan çok, mütegallibenin ve egemen güçlerin temsilcisi konumundadır. Sosyal bir kurum olan 
din önemsizdir ya da zararlıdır; din adamları ise mevcut düzenin yanında yer aldıkları ya da savunucusu oldukları için mücadele edilmesi gereken bir güçtür.

Sınıfsal söylemi esas alan romancılar için bir başka karşıt güç Batı'dır. Batı özellikle istilâcı ve sömürücü özellikleriyle tam bağımsızlığın karşısındaki en büyük engel olarak görülmektedir. Özellikle ulusalcı romancılarda Batıya ait çatışma nedenleri ve bu nedenleri oluşturan ana malzemeler, Anadolu direnişine ait menkıbeleştirilmiş anekdotlardan beslenmektedir.

Dönemin roman yazarlarından kimileri, ülkenin tarihsel süreç içinde geçirdiği değişimi toplumsal, ekonomik ve insanî değerler bakımından ele alarak dikkatleri üzerlerine çektiler. Kimileri de özgün üslûplarıyla, yaşadıkları dönemlerinin siyasal cedelleşmeleri içinde ve aydın bunalımı çevresinde kendi kuşaklarını toplumcu-gerçekçi bir dikkatle sorgulayan eserleriyle Türk romancılığında yeni açılımlar sergilediler. Bu dönemin kimi romancıları da eserlerinin sanatsal derinlikleri yerine siyasal söylemleri ile gündemde kaldılar.

70’li yıllar, aydının/romancının politize olduğu, sınıf çatışmasını körükleyen üçüncü sınıf çeviri romanların, ya da kaba ulusçu söylemlerin ilgi gördüğü, kutupluluğun uç sınırlara vardığı bir dönemdir. Yazılan romanların bakış açıları da çoklukla yazarlarının düşünce yapısına ve okurun ilgisine göre biçimlendi. 12 Mart ve 12 Eylül askeri muhtıra ve darbeleri ile depolitizasyon dönemi başladı. Bir süre bocalama devresi geçiren ve tutukluluk, işkence, tutukevi anılarına yer veren otobiyografik eserlerle oyalanan Türk romanc1ları, kendilerini genel olarak politik, toplumsal ve ekonomik sorunlardan soyutlayarak belki biraz da içselleştirerek bireysel konulara yöneldiler. Böylece sanat eserinde bir şeyi anlatmaktan çok nasıl anlatıldığının önem taşıdığını, romanın yeniden kurma ve yaratma işi olduğunu; yaratma ve anlatma ediminin ise sözcüklerin kullanılışıyla ilgili olduğunu, büyük ölçüde bireysel ve özgün kullanımlara dayandığını keşfettiler. Bu eğilimin sonucu olarak günümüz romancıları artık kendisini Tanrı yerine koyan ve yine kendi ahlâk öğretisi doğrultusunda dünyaya düzen vermeye çalışan klasik ondokuzuncu yüzyıl romancısından farklı olduğunun, ya da insanı ikinci plana iten ve onu eşyanın karşısında önemsiz bir varlık durumuna getiren yeni romancı olmadığının ayrımına vardılar.

Seksenli yıllardan itibaren bireysel bakışın egemen olduğu klasik roman yerini çoğulcu bakışa, çoksesli/çok kültürlü bir bakışı yeğleyen postmodern bakış açısına bıraktı. Yeni açılımlara açık olan dönemin roman yazarları, aydın problemi çevresinde ve büyük kentin sorunları arasında ezilen Türk entelektüelinin bunalımlarını, zamanla hesaplaşmasını konu alan romanlara yöneldiler. Önceki kuşaktan toplumdaki sosyal dengesizlikleri gündeme getirenleri, yeni kuşaktan modern roman tekniklerini eserlerinde uygulayan ve toplumsal sorunlardan bireysel sorunlara geçen romancilar izledi. 
Farklı bir cepheden bakıldığında 1980'li yıllar, romanımız için yeni açılımların da başlangıcı sayılabilir. Ancak topyekün bir başarıdan söz etmek de abartılı bir iddia olur. Birkaç ad dışında, Türk romanı nicelik bakımından gözle görülür bir artış göstermesine rağmen, nitelik bakımından bir düşüşü yaşadı. Bunda medyanın sağladığı olanakların ve cilalı imaj adını verdiğimiz reklamın da önemli etkisi olduğu kesindir. Bir gazete röportajcılığının kolaylığında, daha çok güncele, postmoderniteye ve özümsenmemiş güncel olaylara yönelik magazinel eğilimler, birer yıldız gibi parlayıp söndüler. Birbirine yakın, gazete haberleriyle desteklenen konular, okuru bilgilendirmek, onda yeni ufuklar açmak yerine, derinliği olmayan, hep kolaycılığı benimseyen, üslûp ve teknik endişesinden yoksun içerikleriyle yarı gazeteci, yarı araştırmacı yazarların etkinlik ve ilgi alanlarını genişletmekten öte fazla bir işlevi olduğunu söylemek zor.

Edebiyatın başka alanlarında ünlendikleri hâlde romanı deneyenler, her dönemde olduğu gibi bu dönemde de bir iki eserden sonra bir yıldız gibi parlayıp sönerler. Bunlar arasında kimileri marksist/sosyalist bakış açısından kentin sorunlarını ve kent insanının yalnızlığını, yaşadıkları dönemin sosyal sorunlarını ve toplumsal olayları temel izlek olarak işlerken; kimileri de konularını Doğu-Batı kutupluluğu içinde yurt dışına çalışmaya giden/göç eden işçilerin/göçmenlerin yaşam ökülerinden aldılar. Özellikle sonuncular, romanlarında bu insanların yaşadıkları olumsuz koşulları, gurbet duygusunu, konuk olarak bulundukları ülkelerin insanları tarafindan aşağılanmalarını, ülkelerinde 'gurbetçi', 'almancı' gibi yakıştırma adlarla küçümsenmelerini işlediler. Ne ki bu yazarların büyük bir bölümünün başlangıçta insancıl ve evrensel değerlerle yaklaştıkları Batı'ya ve Batılılara olan iyimser ve hayranlık dolu düşünceleri, tanık oldukları ırkçı tavır ve ötekileştirici dinsel bağnazlıklar sonucunda yerini düşkırıklığına bıraktı.

$\mathrm{Bu}$ dönemin romanını etkileyen unsurların biri de sosyal değişimlerden beslenen ve anlatma tekniklerini esas alan sanat eğilimleri ile ilgilidir. Nitekim 1980'lerden itibaren roman yazmaya başlayanlar, toplumsal sorunları ele almakla birlikte biçim ve sanat kaygısını ön plana çıkardılar. Bu değişimin temelinde Sovyet Bloku'nun çözülmesi, globalleşme, toplumdaki yerleşmiş ahlâk normlarının değişmesi gibi dünyadaki gelişmelerin ve kuşak romancılarını politize olmaktan bir ölçüde uzaklaştıran 12 Eylül askeri darbesinin etkisi olduğu açıktır. Bu yeni açılımın gereği olarak, ele alınan konuların da birtakım zıtlıklara değil, buluşma noktalarına doğru kaydığı dikkati çekmektedir. Artık, olay, olay yeri, olay zamanı ve anlatıcı gibi geleneksel biçim anlayışı dışında, yapısalcı dil kuramlarına göre kurgulanmış yeni roman ögeleri olan simgeler, mitler, yeni imgelerle örülü bir sanat anlayışı, biraz el yordamıyla da olsa, romanda uygulama alanı bulmaktadır. Romanlarda, anlatılan konudan ziyade nasıl kurgulandığ 1 öne çıkmış, anlatım aracı olan dil ise, özellikle yeni romancılar ve onları izleyen postmodern romancılar tarafından başlı başına romanın temel ögeleri arasında sayılmıştır.

\section{TFkP}

Uluslararası Türkçe Edebiyat Kültür Eğitim Dergisi Sayı: 5/2 2016 s. 784-800, TÜRKIYE 
1990'l1 yıllar, postmodern romanın zafer y1lları oldu. Seksenli yıllarda Avrupa'da başlayan mimaride ve müzikte genel üslûbun reddine dayanan bu akım, aklın ve bilimin verilerine dayanan moderniteye, her şeyi bilen hakim anlatıcıya ve modern devlete duyulan güvensizlikten doğmuştu. Ayrıca savaşların sebep olduğu ruhsal çöküntüler ve tepkiler, teknolojinin ve sanal dünyanın hayatın her alanına hakim olmasına ve bunun sonucu olarak romancıların büyük anlatılar yerine mikro düzeyde bireyin iç dünyasını dilsel bir oyun biçiminde veren anlatılara yönelmelerine yol açtı.

Batıda James Joyce, Franz Kafka, William Faulkner.. gibi romancıların başlattığı modernist akım ile Vladimir Nobakov, Alain Robbe Grillet, Michel Botor, Nathalie Sarraute, Claude Simon... gibi yeni romancıların başlattıkları postmodern anlatım teknikleri biraz gecikmeyle de olsa Türk romancıları tarafından uygulanma firsatı buldu. İlk kez 1950'li yıllarda Tanpınar'ın başlattığı klasik anlatma tarzlarının dışında romanın kurgusuna ve anlatım biçimine yönelik bu akımın en belirgin özellikleri, klasik romanda yol gösterici aydın imgesinin yerine her şeyi bilmeyen sıradan bir insan tipini yerleştirmek; okuyucuyu bilinmezlik ve belirsizlik içine sürükleyerek çözümden kaçınmak; üst kültür ve alt kültür ayrımına karşı çıkmak; esere sadece bir kurmaca, yazarın elindekilere ise malzeme olarak bakmak; bol bol gerçek dışına yer vermek; sanat ile gerçek hayat arasındaki bağları koparmak; kurmaca olaylar yanında romanın yazılış serüvenini de romana konu etmek; okuru eserin içine çekerek kendi yorumunu ve sonucunu kurmaya zorlamak; dili bilinene ve geleneksel anlatıma karşı kullanarak okuru metne yabancılaştırmak; yeri geldikçe roman kurgusunun dışına çıkarak roman kişisi ile okur arasında diyalog kurmak ve nihayet roman kişilerinin iç dünyalarındaki karmaşık ruh hâlini verebilmek için alışılmışın dışında farklı anlatım tekniklerine yer vermek... olarak sıralanabilir..

Türk romancıları tarafindan benimsenen ve tutulan bu akım, 2000'li yıllardan itibaren yerini gizemli, düşsel, fantastik ve otobiyografik karakterli; yarı belgesel, bilimkurgusal ve tarihsel romanlara bıraktı. Burada Postmodernizmin temel ilkelerinden biri olan çoğulculuk, yani birbiriyle çelişen farklı doğruların olabileceği düşüncesi üzerine temellenen postmodern tarihsel romanlar ve gelişme süreci üzerinde kısaca durmak istiyorum.

Tanzimattan itibaren hemen her dönemde ilgi gören klasik kurgulu tarihsel romanlar, sürükleyici üslûplarıyla rahat okuyucu bulsalar da, belli bir tarih tezine dayanmadıklarından tarih ve sosyoloji için bir belge niteliği taşımaları dışında roman türüne fazla bir katkı sağlamazlar. Altmışlı yıllara kadar tarihsel olaylara ve dönemin egemen olan ideolojisine bağlı kalınarak klasik çizgide devam eden bu romanlar, yetmişli y1llardan itibaren yerlerini tezli eserlere bıraktılar. Başka bir söyleyişle tarihsel roman, bir tezin gerçekleştirilebileceği bir alan olarak görülmeye başladı. Özellikle seksenli yıllara gelindiğinde sebep-sonuç ilişkisine dayalı, 
belgelerle kanıtlanabilen ve yoruma fazla yer vermeyen nesnel tarih anlayışı da değişti ve kurmaca metnin malzemesi oldu. Artık tek ve mutlak bir gerçeğin olamayacağı, gerçeğin zamanın koşullarına ve bakış açısına göre değiş̧ebileceği, geçmiş tam olarak kayıt altına alınamadığı için olaylar arasında büyük boşluklar olduğu, bu boşlukların farklı biçimlerde doldurulabileceği, hatta dönemin iktidarının görüşleri/ideolojisi doğrultusunda oluşturulduğu için, tarihsel bilgilerin öznellik taşıdığı ve önyargılı olduğu, dolayısıyla kesinlik bildiremeyeceği görüşü taraftar buldu. Edebiyatta ve daha çok kurmaca metinlerde karşılaştığımız tarihsel metinlere yönelik bu tavrın arka planında eserlerinin temel yapısını tarihin bir kurgu olduğu görüşünden yola çıkarak tarihsel metinlerin yazınsal metinler gibi okunabileceği, ya da yeniden üretilebileceği bu yüzden kurgusal metinlerle tarih metinleri arasında bir bakıma fark olmadığ 1 düşüncesi üzerine kuran ve Gülün $A d l$ eseriyle bu alanda öncülük eden Umberto Eco'nun, Tarihi Yeniden Düşünmek adlı eseriyle Keith Jenkins'in, Bilimsel Nesnellikten Postmodernizme: Yirminci Yüzyılda Tarih Yazımı adlı çalışmasılyla Georg G. İggers'in katkıları olduğunu anımsatmak isterim.

Pek çok genç romancının ilk eserlerini verdiği 2000'li yıllar, bu yazının başında ifade edildiği gibi Türk romancıllı̆ı açısından oldukça verimli yıllar olarak düşünülebilir. Her y1l gittikçe artan katılımlarla roman sayısının yıldan yıla artması, bu yargıyı bir ölçüde doğrulamaktadır. Sözünü ettiğim bu romancılardan kimileri edebiyatı içsel bir boşalma olarak gördüklerinden, çoklukla özyaşamöyküsel bir anlatım yolunu benimserken; anlatma sanatında neyin anlatıldığının değil nasıl anlatıldığının önem taşıdığ romanlarıyla dikkat çektiler. Bunun bilincinde olan 2000'li yılların romancılarından farklı adlar altında kümelenen kimileri başarılı anlatım teknikleri, modern ve postmodern akımlara bağlı sağlam kurgulu romanlarıyla uzun süre edebiyat ve sanat dergilerinin gündeminde kalmayı başardılar. Kimileri ise 80 sonrası idealleri, enerjisi tükenmiş, ümitlerini yitirmiş üniversite gençliğinin kimlik arayışlarını ve gelecek endişelerini işleyen romanlara yöneldiler.

$\mathrm{Bu}$ gruplara islamcı romancıların din, yozlaşma, hidayete erme, sistemle çatışma ya da entegrasyon gibi temaları bünyesinde barındıran islami romanları da katalım. Söz konusu romancıların ilk başlarda açık mesajlı ve niteliksiz eserlerinin giderek entelektüel bir boyut kazandığını ve nitelikli ve mistik karakterli romanlara yöneldiklerini de vurgulamak istiyorum.

Genç kuşak romancıların ilgi duyduğu alanlardan biri de fantastik romanlar ve bilimkurgu romanlarıdır. Daha çok Amerikalı ve Rus kökenli romancıların tekelinde bulunan bu alan, başarılı Türk romancıları tarafından doldurulmaya çalışılmaktadır. 
2000'li yılların romanlarında dikkati çeken en önemli husus, konularını Türkiyenin gündemini tutan olaylardan, tartışmalardan almış olmalarıdır. Bu çerçevede bir roman yoğun ilgi gördüğü an birçok benzeri hemen piyasaya sürülmektedir.

2000'li yıllarda yazılan roman konulara gelince bu konuların iki ayr1 mecrada yoğunlaştığı dikkati çekmektedir. Bunlardan ilki 12 Eylül döneminin baskıcı ortamının da etkisiyle 1980'li yıllarda bireyin iç dramını ve duygusal ilişkileri konu alan romanlar; diğeri ise doğrudan Türkiyeyi meşgul eden komplo teorilerine dayalı aktüel konularla ilgili romanlardır. İkinci gruba girenleri, daha çok politik kurgu ya da fantastik roman adlarıla tanımlamak mümkün.

Son yıllarda Türkiye'de esen mevsimlik rüzgârlar, çok geçmeden edebiyatımızda en başta romanda yankı buldu. Susurluk kazasının ardından devlet-siyaset-mafya üçgeninde komplo teorisine dayalı, pek adlarını duymadığımız istihbarat örgütleriyle içli dışlı ilişkileri ele alan romanların yayınlanmasına yol açtı. Son yıllarda Amerikan saldırganlığının artması ve 2003 y1lından itibaren ise ABD'nin Irak'1 işgal etmesi ve Kuzey Irak’ta ülkemizin bütünlüğünü tehdit eden politikalar üretmeleri sonucu komplo teorisi üzerine kurgulanmış romanlarda âdeta bir patlama yaşandi.

Bu türde ilgi gören konulardan biri de Türkiye ekseninde gelişen bölgesel ve global düzeydeki ilişkileri konu alan romanlardır. Bunların en popüler olanı Halil Kanargı'nın Akreple Dans ve Hakan Yel'in Sultan'a Dokunmak adlarını taşımaktadır. Romanların 5000'in üzerinde satması Türk okurunun nelere takılıp kaldığını ve ilgi alanlarını göstermesi bakımından dikkate değer. Aynı paralelde kaleme alınan cinayet romanları, faili meçhul cinayetler, soğukkanlı katiller, misyonerlik çalışmaları, Siyonizm, Sabataycılık, İsrail'in gizli emelleri, Türkiye'yi içerden çökertmek isteyen örgütler, uyuşturucu ticareti, derin devlet, mafya, gizli servisler, ajanlar, örgütler bu tür romanların değişmez figürleri ve aksesuarları olarak kullanıldılar.

Konusunu mitolojiden ve gizemli tarikatlardan alan Dan Brown'un Da Vinci'nin Şifresi paralelinde yazılmış romanlardan İblis, Kuantum Şifresi, Tahinci Şifresi dikkati çeken ve tutulan romanlardır. Bu romanların ve yukarıda adlarını andıklarımızın düzeyini Tahinci Şifresi yazarı Adem Özyol'un söylediği “İnsanlar 50 milyon verip Cem Yılmaz'la keyifleniyorsa 5 milyon verip bu kitapla da keyiflensin istedik" sözü roman sanatının ne ölçüde dikkate alındığı, kalite anlayışı ve tüketime yönelik rant amaçlı olduğu hakkında yeteri kadar bilgi vermektedir.

Burada adını andığım türün nasıl yozlaştırıldığını vermek için iki ilginç örnek üzerinde durmak istiyorum: Bunlardan ilki Kızıl Vaiz, Kara Gezgin adlı bilimkurgu romanlarından tanıdığımız Burak Turna, Orkun Uçar adlı iki genç tarafından 2004 yılında yayımlanan Metal 
Fırtına'dır. Roman pek çok dil ve anlatım yanlışına ve yazınsal değeri olmamasına rağmen baskı sayısını 100 binlere ulaştırmayı başardı. ABD’nin bor madenlerine sahip olmak için 23 Mayıs 2007'de Türkiyeyi işgalini konu alan romanın gördüğü aşırı ilgi ve doğal olarak elde edilen gelir, hem ortakları birbirine düşürdü, hem de ayrı ayr1 ikinci ve üçüncü ciltlerinin yazılmasına sebep oldu. Bu tür romanlara gösterilen ilgi öylesine arttı ki Türk-ABD savaşını konu alan pekçok versiyonu seri hâlde üretilip piyasaya sürülmekte gecikmedi. Tüketim toplumunun isteğine uygun olarak ve ulusumuzun son zamanlarda kırılan gururu ve yaşadığımız eziklik aşırı ölçüde sömürülerek akla gelebilecek her yol denendi. Söz gelişi Metal Fırtına 2'de Türk ajan Arap teröristlerin yardımıyla Washington'un önemli merkezlerini havaya uçururken, Amerika Bizimdir'de ABD düşmanı bir uzaylının yardımıyla Amerika ele geçirilir ve roman kahramanları Oval Ofis'te tavana köfte yapıştırma figürleriyle çiğ köfte partisi düzenlerler. Doğal olarak başkanlık koltuğuna İstanbul Ülkü Ocakları Başkanını oturtmayı da ihmal etmezler. Böylesine uçuk ve roman parodisi diyebileceğimiz yayınlar, bir yanlarıyla incinen Türk gururunu onore etmeye çalışırken farkına varmadan Türklüğü gülünç duruma düşürdüler.

İkinci vereceğim örnek, polisiye ve aşk gibi popüler konularda roman yazan Osman Aysu. Aysu, seri roman üreten yazarlardan biri. Kendi ifadesiyle, iki ayda bir roman yazan ve yılda en az üç kitap yayımlayan bir romancı. Çok satanlar listesine pek az girmiş, ama umurunda değil böyle şeyler. Çok geç yaşlarda başladığı roman yazma çalışmalarını on üç yılda kırk beş kitapla sürdürüyor. Doğal olarak roman kahramanının anlatım bozuklukları, adının ilerleyen bölümlerinde sık s1k değişmesi, öksüz, yetim olarak tanıttığı kişilerinin romanın bir yerinde anne ve babalarıyla buluşmaları, bir romanının başka adlarla farklı yayınevlerince basılması gibi bir sürü çelişkileri de beraberinde taşıyarak. Aysu'nun bitmiş bir kitabı okuyup düzeltmek gibi “sıkıcı" âdeti de yok. Bütün bu zayıflıklarına rağmen eserini basacak yayınevleri bulduğuna göre herhâlde okur bulma derdi de yok. Aysu, roman yazmaktan bıkmış olacak ki Cem Erciyes'le yaptığı bir söyleşide artık film senaryosu yazacağını söylemektedir. (Erciyes, Radikal-Kitap 207: 16) Sanırım bu örnek son yıllarda romanda görülen patlamayı daha iyi anlatmaktadır, tabii nitelikli olan pek çok eseri bu yargının dışında tuttuğumu da belirtmeliyim.

Benzer yozlaşmayı yukarıda ana çizgileriyle tanıttığım yeni tarihselcilik anlayışıyla kaleme alınan postmodern tarihsel romanlarda da görmek mümkün. Şöyle ki çoğulculuğu ve tarihteki olayların tek bir doğru ile açıklanamayacağı temel düşüncesinden yola çıkan romacılar arasında kimileri işi yerleşmiş değerleri alt üst ederek ve bilinenleri çarpıtarak kendi ideolojileri doğrultusunda bir yol izlediler. Bu kasıtlı ve yanlış tutum, ister istemez romancının tarihi kurgulamadaki özgürlüğünün sınırının ne kadar olacağı sorusunu gündeme getirdi. Ne ki romancnın bu tutumunu sırf sanatsal yöntemlerle ve kamuoyu/okuyucu baskısıyla engellemek 
mümkün değil. Bugün popülizmin ve ideolojilerin kıskacında olmakla suçlanan tarihsel romanın içinde bulunduğu açmazı bir eleştirmenimizin cümleleriyle sorgulayayım: "Geçmişi, okuyucusuna mesaj vermek üzere, kendi inançları/bakış açısıyla kendi amaçları doğrultusunda tahrip etmenin önünde ne yazık ki yasal bir engel yoktur.' (Boynukara, 2007: 462).

Son yıllarda ülkemizde Avrupa Birliğinin iki yüzlü politikaları sonucu AB karşıtı bir cephenin oluşmasına yol açtı. Kamuoyunun bu tepkisini çok iyi gören kimi romancılar güçlenen ulusalcı akımın isteği doğrultusunda ulusal kaynaklara yöneldi. Özellikle ikibinli yılların başında görülmemiş bir rekora koşan ve Milli Mücadeleyi anlatan Turgut Özakman'ın Şu Çılgın Türkler'i sözünü ettiğim ulusal refleksin ve tepkinin sonucudur. Kurmaca yönünün oldukça zayıf olduğu, bireylerin değil kitlelerin anlatıldığı ve belgesel bir özellik taşıyan roman, sosyolojinin konusu olabilecek baskı sayısına, 700'lere ulaştı. Doğal olarak benzerlerinin yazılması gecikmedi ve roman sayısında yıldan yıla büyük bir artış görüldü. Bu arada Şu Çılgın Türkler'le konusu örtüşen Attila İlhan'ın Allahın Süngüleri ve Gazi Paşa romanlarını, edebi değeri ve kurmaca dünya oluşturması bakımından anmak bir vefa borcudur.

Tüm bu çeşitliliğe rağmen ekonomik sıkıntı çeken milyonların yaşamları pek az romanda gündeme taşındı. Bu konu kısırlığı içinde tüm kentleri, kasabaları, köyleri ile ve bünyesinde barındırdığı pek çok sorunu ile Anadolu yine unutuldu. Ya da Türkiye'yi metropollerden ibaret gören genç romancılar tarafından yeterli ilgi göremedi. Nedense genç kuşak romancılar romanlarının konularını yoğun tüketim merkezlerinde, büyük metropollerde ve bu metropolleri simgeleyen Şişli, Mecidiyeköy, Etiler, Beyoğlu... gibi 'sosyelit' mekânlarda toplama kolaylığını seçtiler. Sonunda "fanteziden bireysel çözümlemeye, postmodern denemelerden polisiyeye ve kurmaca merakına kadar hemen her eğilimden 'sırf edebiyat olsun' diye pek çok ilginçliğin sergilendiği romanlar” birbirini izledi. (Torun, Kitap-Haber 14: 31).

Geçen yıllarda olduğu gibi roman yazarlarının kimlikleri arasında da eskiye göre birtakım farklılıklar dikkati çekti. Eskiden roman yazarlarını mesleklerine göre gruplandırmak biraz kolaydı. Zira bu meslekler öğretmen, gazeteci gibi birkaç meslekle sınırlıydı. Oysa günümüzde bu meslek dalları da çeşitlendi ve hemen her alana yayıldı. Söz gelişi iş adamları eskiden pek roman yazmayı düşünmezlerdi, zira buna ayıracak ne zamanları ne de roman yazmak için donanımları vardı. Ama şimdilerde akademisyenler iş adamları, sahne sanatçıları ilk sıralarda yer almasalar da dikkat çekecek ölçüde sayılarını artırdılar. Sonra gazeteciler, tiyatrocular, radyo, TV sunucuları, reklam şirketi sahipleri vb. listeye katıldılar.

$\mathrm{Bu}$ yazının başında kısaca dikkat çektiğim Türk romanının nicelik olarak ulaştığı yeri yeniden sorgulamak istiyorum. Kuşkusuz Türk romanının ulaştığı bu sonuç bizi hem romanımız 
açısından iyimser olmaya, hem de nitelikleri bakımından üzerinde düşünmeye ve özeleştiri yapmaya zorluyor. Bunun için ilkin türe duyulan ilginin sebepleri üzerinde duracağım.

Her şeyden önce 80'li yıllardan başlayarak hayatımıza giren bilgisayar ve internetin bilgiye ulaşmada sağladığı olanaklar, masaüstü yayıncılığın sağladığı açılımların sınırsızca kullanımı, buna bağlı olarak dizgi ve baskı işlerindeki kolaylıklar, yeni yayınevlerinin genç romancılara kapılarını açmaları ve nihayet ucuz kitap yayımlayan yayınevlerinin sundukları fırsatlar, yazar-yayıncı-okur açısından yüreklendirici bir rol oynadılar.

Roman türünün bu denli ilgi görmesinde kuşkusuz okurun da büyük payı var. Şöyle ki okur romanı görsel medyanın bir parçası gibi algılamakta; romana olan ilgisi de biraz reklamın ve güncel olayların, seyir kültürünün etkisi altında oluşmaktadır. Söz gelişi Orçun Uçar-Burak Turna'nın yayımladıkları Metal Fırtına'nın, Turgut Özakman'ın Şu Çılgın Türkler romanının ulaştığı tirajı bu açıdan değerlendirmekte yarar var. Bunlar arasında özellikle başarı grafiği hızla yükselen bir akademisyen romanciya dikkat çekmek istiyorum: İskender Pala. Roman yazma amacını ilk romanı Babil'de Ölüm İstanbul'da Aşk'ta Divan şiirini gençlere tanıtmak, benimsetmek, sevdirmek gibi soylu bir düşünce ile kamufle ederek açıklayan Pala, daha sonra gençliğin nabzını tutan ya da birtakım hazır tarihsel çerçevenin içini geleneksel anlatının söz kalıpları ve klasik şiirin özgün örnekleri ile doldurarak kaleme aldığı popüler nitelikli romanlarını çok abartılı reklam kampanyaları ile destekleyerek geniş okuyucu kitlelerine ulaştırmayı başardı. Doğal olarak baskı kalitesi, dizgi, kapak, özgün format gibi romanlarda görselliği sağlayan unsurları da bu bağlamda değerlendirelim.

Yazarların roman yazma nedenlerine gelince bu konuda birçok sebep sayılabilir. Ancak bu sebepler içinde belki başında küresel iletişim olanaklarının ve görselliğin de büyük payı var. Görsel ve yazılı basında, özellikle internet sayfalarında boy göstermek, görkemli kitap kapaklarında, söyleşilerde, yorumlarda anılmak, ekranda görünmek, hangi meslekten olursa olsun insanlarda roman yazma hevesi uyandırmaktadır. Tüm bu nedenlerin arka planında okur eğilimlerine paralel olarak romanın öteki türlere oranla maddi ve manevi kazanç sağlama aracı görme anlayışının da oldukça etkili olduğunu söyleyelim.

Öte yandan romancı, artık sanat eserinin geniş kitlelere ulaşmasında reklamın önemli payının olduğunun farkına varmıştır. Hatta denebilir ki kitapların okuyucuyla buluşmasında nitelik kadar tiraj kaygısı da ön plandadır. Nitekim daha önce bilinen "iyi eser okuyucusunu bulur" genel yargısı bugün de geçerli olmakla birlikte iyi bir reklamın sanat eserinin başarısında önemli katkıları olduğu yadsınamaz bir gerçek olarak durmaktadır. 
Bu konuyu fazla genelleştirme yapmadan Ahmet Oktay'ın günümüz romancıları için söylediği şu yargı ile kapayacağım: Ahmet Oktay'a göre "Toplumsal adalet düşüncesine ve ahlakî sorumluluğa karşı duyarsızlaşmış, oyuna gömülmüş, kendi yazınsal geçmişinde okuyacak tek bir yazar bile bulamayan, geçmişini hakir gören, iddiaları kendinden menkul bir bölük romancidır." (A. Oktay, 2003: 15).

Günümüzde global ölçüde dünya romanın özelde ise çağdaş Türk romanının önemli sorunu olarak gördüğüm imaj yükleme ve algı oluşturmada reklamın işlevi ve etkisi üzerinde durmak istiyorum. Bilindiği üzere günümüzde kimi eleştirmenler nitelikli romanın ölmekte olduğunu söylüyor. Bu doğru değil. Ama romanın önemli bir değişim geçirdiği kesin. Bu değişim, daha çok mimetik romanın temelini oluşturan yüksek ve evrensel değerler yerine günü birlik basit ihtiyaçları karşılamak için yeni bir kimlik edinmek ve kabuk değiştirmek biçiminde karşımıza çıkıyor. Zira bugün dünyada olduğu gibi bizde de artık roman, piyasa içinde tüketilen bir tüketim malzemesi, bir meta hükmündedir. Doğal olarak romandaki bu olumsuz değişimi tek bir sebebe bağlamak zor. Bu sebeplerin başında romanın hedef kitlesi olan roman birikimi bakımından donanımsız okurlar geliyor.

Onların roman okuyarak zaman geçirmeye tahammülleri yok. Roman onların isteklerine, ihtiyaçlarına cevap verebilecek mi? Bunun için günümüzün en geçerli sözcüğü devreye giriyor: İmaj. Yani önemli olan eser/ürün değil, ürünün kitleler üzerinde oluşturduğu alg1.

$\mathrm{Bu}$ algıyı oluşturmanın çeşitli yolları var: En başta geleni nasıl, ne şekilde olursa olsun ürünü gündemde tutmak; görsel ve işitsel araçlarla zihinleri esir almak. Bu esir alma işini daha çok yayıncılar reklam kampanyalarıyla gerçekleştiriyorlar.

Reklam iki yönlü işliyor: İlki yazarın, sonra eserin tanıtımını yapmak. Yazarı yüceltmek, bir bakıma eserini yüceltmek anlamına da geliyor. Bu yüzden henüz yayınlanmamış olan roman için yapılan iki sayfalık röportaj, görsellerle desteklenen yazarın imaj yüklü fotoğrafları ile dolduruluyor. Bilbordlar, ilan panoları nereye baksanız o eserin/eserlerin imaj yüklü resimleriyle kuşatılmış. Bir çeşit cilalı imaj devrini yaşıyoruz.

Bu cilalı imaj yüklü pazarlamacılığa karşı çıkabilecek iki önemli güç var: Biri bilinçli okur, öteki eleştirmen. Birinci ile ilgili olarak biraz ihtiyatla söylüyorum, pek çoğu, kendisine sunulandan daha fazlasını beklemiyor. Gördükleriyle yetiniyor. Zaten çoğunluğun iyi edebiyata ihtiyacı da yok. Çünkü çevresinde kendisini oyalayacak o kadar çok şey var ki. Öte yandan günümüz insanlarının istekleri de, hayat tarzları ile paralel yürüyor. Artık insanlar TV'den izlediklerini, gazetelerden okuduklarını, internette gördüklerini, yani sanal dünyanın 
sunduklarını ve dahası kendisinin de katıldığı bir hayatı anlatmasını bekliyor romancıdan. Kaldı ki tüm sırların, gizli bilgilerin facebook, tvitter aracılığıyla ortalığa saçıldığ bir dünyada $S u c ̧ v e$ Ceza'daki Raskolnikov'un iç çatışmasını, Reis Bey oyunundaki ağır ceza reisinin yaşadığı vicdan azabını, Saatleri Ayarlama Enstitüsü'ndeki Hayri İrdal'nn çevresine ve dünyaya muzipçe ve ironik bakışını anlamasını beklemek ne kadar gerçekçi? (Kurt, Kitap-Haber 14: 26).

Eleştirmene gelince o da kendinden bekleneni verebilecek durumda değil. Çoğu kez eleştirmenler de reklam panolarından besleniyorlar. Bunu kitap arkasındaki birbiri ardınca sıralanmış takriz yazılarından anlamak mümkün.

Eğer bir kitap yüz bin ve üzeri baskı yapmışsa okurun onu almaktan başka çaresi yok gibi. İnsanlar o kitabı okuduğunu, ya da okumakta olduğunu göstermek için sürekli yanlarında taşıyor, ya da sözü evirip çevirip o kitaba getiriyorsa, ya da romanın yazarı henüz kitap piyasaya çıktı̆̆ı gün romanının başarısı ile ilgili ahkâm kesiyorsa eser değil pazarlama öne çıkmıyor mu?

Ankara'da büyük bir yayınevi kitap satın alan müşterileri arasında kitap alma nedenleri hakkında yaptığı bir anket sonucunda \% 75'inin kitap kapaklarına ve arkasındaki takriz yazılarına bakarak aldıklarını belirlemiş. Bilinçli olarak kitap alanların oranı ise ancak \% 10 nispetinde.

Eskiden eseri tanıtmanın yolu kitap hâlinde yayınlanmadan önce bir gazetede tefrika ettirmekti. Söz gelişi Cumhuriyetin ilk yıllarında Son Saat, Son Telgraf ve Vakit gibi bulvar gazetelerinde en az dört hatta altı romanın farklı sayfalarda tefrika edildiğine rastladım. Para kazanma kaygısı içindeki yazar da sözü uzatabildiği oranda gazetenin hızla artan tirajından nemalanmış oluyordu. O yazarların çok az bir kısmı bugün eserleriyle bize ulaşabildiler. Ama o dönemdeki gazetenin kurnazlığı bugünün reklam kampanyaları karşısında çok nahif kalıyor.

Eskiden çok bilinen bugün de doğruluğuna inanmak istediğimiz bir kural vardı: İyi eser okuyucusunu bulur. Bu söz çok doğru ama cilalı imaj devrini yaşadığımız günümüzde özellikle roman alanında değişmez bir doğru olarak yaşayacak mı? Yoksa yerini iyi imaj ve reklam, niteliğine bakılmaksızın her eseri sattırır, okurla buluşturur yargısına mı bırakacak?

Oysa eleştirmen, okur için yegâne ufuk açıcıdır, bir kılavuzdur. Artık bu işi imajmaker'ler yapıyorlar. Söz gelişi bir yayınevi, ünlü bir yazarın herhangi bir kitabı, filan yayınevinde yıllarca raflarda fersudeleşirken, bir başka yayınevinin elinde yok satıyorsa bunun tek nedeni reklam ve eserin kazandığı yeni imajdır. Bu durumda okur, yayımlanan bütün eserleri okuyamayacağına göre yine iş eleştirmenin kılavuzluğuna kalıyor. Sanat, tabii konumuz olan roman, öykü her şeye rağmen eleştirmenin gösterdiği 1şı̆̆ın peşinden, açtığı yoldan gitmek zorundadir. 
Eleştirinin temel dinamiklerinden biri de kuşkusuz üniversitelerdir. $\mathrm{Ne}$ ki üniversitelerimiz kültürel ortam oluşturma bakımından Batı ülkeleriyle karşılaştırıldığında kendisinden beklenenin oldukça uzağında kalıyor. Esasında yetişmiş eleman olarak büyük bir potansiyele sahip olmasına rağmen, yeteri kadar eleştirmen yetiştirmediği gibi edebiyata katk1 sağlayacak sanatsal ürünler üretmekten de yoksun. Bir eleştirmenin söylemiyle söyleyeyim: "Göstergelerin değil, görüntülerin; eserlerin değil, markaların; kendisinin değil, imajının dolaştığı bir ortamda (gerçek) eleştirmenlere (ne kadar) çok ihtiyacımız var." (Kurt, KitapHaber 14: 26).

Buraya kadar yoğunlaştırarak verdiğim bilgiler 1şığında Çağdaş Türk romanının sorunları ve romanda yeni açılımlar başlığı altında yaptığım değerlendirmeleri şöyle sonlandırmak istiyorum: 1960-2000 yılları, hızlı bir değişim yaşayan Türk toplumunda roman yazarları bakımından verimli yıllar oldu. Medyayı da arkasına alan yazarlar / romancılar, öne çıkan gazeteci-yazar kimlikleriyle eserlerinin niteliksel yanını ve romancı kimliklerini gölgede bıraktılar. Özellikle 80'li yıllardan itibaren depolitize olan toplumsal yapı, gerçeklerden uzakta, tepkisiz ve duyarsız, biraz da dönemin nimetlerine boyun eğmiş bir yazar ve okur kitlesi oluşturdu. Ancak, bu 30 yıl içerisinde iyi şeyler de oldu. Ülkenin hızlı bir değişim yaşadığı, ihtilaller, muhtıralar siyasal dalgalanmalar gördüğü bu dönemde yaşananların pek çoğu, estetik bakımdan düzeysizliklerine rağmen, romanlarda yankısını bulmakta gecikmedi. Tüm kurumlarıyla ve çatışmalarıyla toplumsal hayat; toplumdaki değişim süreci ve bu süreçte yaşananlar; Anadolu coğrafyası ve sorunlarıyla köy hayatı; bu hayatın yerel renkleri, kültürel ve folklorik zenginlikleri; batılılaşma ve çağdaşlaşma serüveninde yaşanan kimlik sorunu, geçiş dönemi bunalımları; eski kurumlarla onların yerini alanlar arasındaki değişim / dönüşüm sancıları / çatışmaları, bozulan değer yargıları ile yeni bir kimlik edinme çabaları; ara rejimler, ihtilaller ve değişen değer yargıları; köylü kimliğinden kentli ve sanayi toplumuna geçiş sürecinde yaşananlar; sanayileşme ile gelen göç, emek-sermaye, işçiişveren ilişkileri / çatışmaları ayrıntılarıyla romanlara yansıtıldı. Postmodern, modern, fantastik roman akımları farklı biçim ve anlatım teknikleri denenerek hatta geleneksel anlatma formlarından da yararlanılarak romanlarda uygulandı. Öte yandan günümüze hakim olan cilalı imaj anlayışının gereği olarak romanın sadece içeriği değil, kapağından adına, dizgisinden boyutlarına kadar görsellik ön plana çıktı.

$\mathrm{Bu}$ konudaki düşüncelerimi Türk romanının gelişme çizgisinde önemli yeri olan bir romancımızın ifadesiyle sonlayayım: Yukarıda değindiğim tüm olumsuzluklarına rağmen biraz ihtiyatla dahi olsa Türk romanının "dünya romanının en üst çizgisine ulaş(tığı)"nı (Demir, 1990: 21) söyleyebilirim. 


\section{Kaynaklar}

ANDAÇ, F. (1998). Romanda ve Öyküde Yeni Açılımlar 1940-1950. Cumhuriyet Dönemi Türk Edebiyat1, Cumhuriyet dönemi Türk Edebiyatı Sempozyumu 22-22 Kasım 1998, Ankara: Edebiyatçılar Derneği Yay.

BOYNUKARA, H. (2005) Post-modernin mi Var Derdin Var. Dergibi.

BOYNUKARA, H. (2007). Gerçeği Besleyen Kurgu, Kurguyu Besleyen Gerçek, Roman ve Tarih: Tarihi Roman, II. Kayseri ve Yöresi Kültür Sanat ve Edebiyat Bilgi Şöleni 10-12 Nisan 2006, Kayseri: Erciyes Üniversitesi Yayınları.

[BÖRTECENE] A. Oktay. (2003). Romanımıza Ne Oldu? 1. Bs. İstanbul: Dünya Aktüel Yay.

[DEMIR] K. Tahir. (1991). Notlar / Roman Notlar1 1. (haz. Cengiz YAZOĞLU). İstanbul: Bağlam Yayınları.

ECEVIT Y. (2008). Post-modern Türk Romanında Osmanlıca Kullanımı. Hece Düşüncede, Edebiyatta, Sanatta, Modernizmden Post-modernizme Özel Sayıs1 138-139-140, Ankara: İletişim Yay.

ERCIYES, C. (2007) Başka Bir Zamanın Yazarı. Radikal Kitap 207.

GÜNDÜZ, O. (2005). 2004 yılında Romanlarımız ve Romancılarımız. TYB Türkiye Kültür ve Sanat Yıllığı, Ankara.

GÜNDÜZ, O. (2005). Cumhuriyet Dönemi Türk Romanı. Yeni Türk Edebiyatı El Kitabı 18392000. (Ed. Ramazan KORKMAZ, vd.). (2. baskı). Ankara: Grafiker Yay.

GÜNDÜZ, O. (2006) 1960 Sonrası Türk Romanı, Türk Edebiyatı Tarihi - 4 (Ed. Osman HORATA, Ramazan KORKMAZ vd.). İstanbul: KB Yayınları.

GÜNDÜZ, O. (2008). 2007 yılında Romanlarımız ve Romancılarımız. TYB Türkiye Kültür ve Sanat Ylllı̆gl, Ankara: TYB Yayınları.

GÜNDÜZ, O. (2012). İhsan Oktay Anar'in Kurgu Dünyast, Anar'ın Kurgu Evreninde Postmodern Bir Gezinti. (2. bask1). Ankara: Grafiker Yay.

KURT, M. (2003). Romanın Ateşle İmtihanı. Kitap Haber-14, İstanbul.

KUTLU, A. (1998). Roman ve Öykünün Konu Alanındaki Genişlemeler. Cumhuriyet Dönemi Türk Edebiyatı, Cumhuriyet Dönemi Türk Edebiyatı Sempozyumu 20-22 Kasım 1998, Ankara: Edebiyatçılar Derneği Yay.

PAMUK, O. (2.1994). Roman Çă̆ı Başlıyor. Türk Edebiyatı 244.

[SOLOK] C. Kudret. (2004). Türk Edebiyatında Hikaye ve Roman 3, 1923-1959 Cumhuriyet Dönemi. (1. baskı). İstanbul: Dünya Kitapları.

TANPINAR, A. H. (1977). Bizde Roman I-II Edebiyat Üzerine Makaleler. (2. bask1). İstanbul: Dergâh Yay.

TORUN, Ş. (2003). Türk Romanının Popüler Serüveni. Kitap Haber-14, İstanbul.

TÜRKEŞ, A. Ö. (2008). Roman 2007. Virgül, 2(115). 